\title{
Understanding Domestic Violence in India During COVID-19: a Routine Activity Approach
}

\author{
Akshaya Krishnakumar ${ }^{1}$ (D) $\cdot$ Shankey Verma ${ }^{1}$ (D) \\ Received: 30 September 2020 / Accepted: 30 December 2020 / Published online: 10 March 2021 \\ (C) The Author(s), under exclusive licence to Springer Nature B.V. 2021
}

\begin{abstract}
Domestic violence, a prevalent problem in India, saw an increase during the lockdown imposed to contain the spread of COVID-19. This article explores the factors associated with an increase in domestic violence incidents during COVID-19 by applying routine activity theory (RAT) framework. Data were drawn from the incidents of domestic violence reported in newspapers. Data was analyzed using content analysis and three major themes, i.e., three principle components of RAT - motivated offender, suitable target, and absence of capable guardian-were drawn. Findings reveal that sources of motivation in domestic violence perpetrators during the lockdown were alcohol and unemployment. The symbolic value that perpetrators associated with women, lower inertia, visibility, and accessibility to the perpetrators made women suitable targets of domestic violence. Lastly, shortage of police force and travel restrictions on formal and informal sources resulted in the absence of capable guardians. We conclude that changes in the routine activities of people during the COVID19 lockdown provided more opportunities to the perpetrators of domestic violence.
\end{abstract}

Keywords Domestic Violence $\cdot$ India $\cdot$ COVID-19 $\cdot$ Lockdown $\cdot$ Routine activity theory

\section{Introduction}

Protection of Women from Domestic Violence Act, 2005 defines domestic violence ${ }^{1}$ as physical, sexual, verbal, emotional, and financial abuse against a woman by her partner or family members residing in a joint family (Kalokhe et al. 2016) and also includes unlawful

\footnotetext{
${ }^{1}$ Domestic violence is a broad term that includes violence from a partner, child abuse, and elderly abuse. However for this article, domestic violence, unless specified, would mean violence against women from their partner/husband only.
}

Shankey Verma sverma@jgu.edu.in; shankeyverma2704@gmail.com

Akshaya Krishnakumar akshaya.k96@gmail.com

1 Jindal Institute of Behavioural Sciences, O.P. Jindal Global University, Sonipat, Haryana, India 
dowry demands (Ram et al. 2019). Domestic violence is a public health concern and has adverse effects on the physical and mental health of women (Abramsky et al. 2011). India shares a significant global burden of domestic violence. Data from the National Family Health Survey 2015-16 shows that $31.1 \%$ of the ever-married Indian women aged between 15 and 49 years experienced spousal violence and almost $4 \%$ experienced violence during any pregnancy (International Institute for Population Sciences (IIPS) and ICF 2017). According to the National Crime Records Bureau's (NCRB) latest data, domestic violence against women topped the list of categories of violence against women in India. Almost 90,000 cases related to crimes against women were registered in 2018. Out of these, almost one-third were related to cruelty by husband or his relatives (Outlook 2020).

Studies related to domestic violence in India are well documented. It is also acknowledged that domestic violence is associated with education, employment status, caste, and religion of women (Garg et al. 2019), sex of firstborn child (Weitzman 2019), alcohol consumption by husband (Ram et al. 2019), dowry (Pallikadavath and Bradley 2019), asthma, genital sores or ulcers, genital discharge, and sexually transmitted diseases (STIs) (Pengpid and Peltzer 2018), abortion (Stephenson et al. 2016), justification for wife beating (Begum et al. 2015), multiple sex partners of husband (Sinha et al. 2012), and controlling behavior by husband (Dalal and Lindqvist 2012).

Evidence from previous literature also suggests that violence against women increases during and post disasters. For instance, Rao (2020) examined intimate partner violence (IPV) and correlates among Indian women before and after the Indian Ocean tsunami of 2004. She found that IPV against women increased by $48 \%$ from 2005 to 2015 indicating how the demographically vulnerable factors become risk factors for IPV after a disaster (Rao 2020). Similar findings were inferred from another study conducted on Sri Lankan women during the tsunami (Fisher 2010). Fisher (2010) reported that women in tsunami affected areas were vulnerable to physical and sexual abuse. The study further noted that domestic violence continued beyond the tsunami period (Fisher 2010). Parkinson (2019) also noted an increase in and new cases of domestic violence in Australia post Black Saturday bushfires in 2009. Despite these evidences, there is a dearth of research related to domestic violence during pandemics in India.

\section{Domestic Violence During COVID-19}

There is a preliminary evidence to conclude that domestic violence during the COVID-19 increased globally. The restrictions imposed to curb the spread of virus resulted in an increase in violence. For instance, the frontline practitioners dedicated to support victims of domestic violence in Australia reported an increase in the frequency and severity of violence against women during COVID-19 (Fitz-Gibbon et al. 2020). There was an increase in new violence incidents as well. Around $42 \%$ of the Australian practitioners noted an increase in first-time family violence reporting by women (Fitz-Gibbon et al. 2020). Mahase (2020) reported a 60\% increase in emergency calls related to violence against women by their intimate partners in Europe. Similarly, Agüero (2020) found a 48\% increase in helpline calls related to domestic violence in Peru. While analyzing tweets related to domestic violence, Xue et al. (2020) highlighted that tweets mentioning an increase in domestic violence due to COVID-19 were frequent (Xue et al. 2020).

Regarding domestic violence during the COVID-19, only a few empirical published studies are available. For instance, a study on Ethiopian women found that almost one in four women 
experienced any form of domestic violence during the COVID-19 pandemic. Housewives aged less than 30 years, and with arrange marriage were at greater odds of experiencing domestic violence (Gebrewahd et al. 2020). Piquero et al. (2020) examined the association between stay-at-home order in Dallas and domestic violence during COVID-19. Using data from Dallas Police Department, they found an increase in domestic violence in the first two weeks after the lockdown was imposed and a decrease later (Piquero et al. 2020). Sediri et al. (2020) reported that violence against Tunisian women increased during the lockdown. Further, it was positively associated with depression, anxiety, and stress (Sediri et al. 2020). These studies can only be considered the first step towards a more profound understanding of domestic violence during COVID-19.

\section{Domestic Violence in India during COVID-19}

On 22nd March 2020, the Prime Minister of India announced a nationwide lockdown for one day. This lockdown was subsequently extended for a week, then for 21 days and finally until 3rd May 2020 to contain the spread of COVID-19. India declared COVID-19 a "notified disaster" under the Disaster Management Act, 2005 (Sharma et al. 2020). Extended lockdown and other social distancing measures imposed to curb the pandemic made women more vulnerable to domestic violence. Women were fighting a shadow pandemic inside their homes (UN Women 2020).

National Commission for Women's (NCW) data showed that domestic violence complaints doubled after the nationwide lockdown was imposed in India (Vora et al. 2020). Tamil Nadu Police reported an increase in domestic violence complaints. They received approximately 25 calls every day during the lockdown period and registered at least 40 such cases (Kannan 2020). Similarly, Bangalore Police reported a spike in complaints from 10 calls to 25 calls every day from the victims of domestic violence (Peter 2020). These data from different sources indicate that domestic violence incidents increased across the country during the lockdown. On the contrary, organizations such as Jagori, Shakti Shalini, and AKS Foundation reported a decrease in complaint calls related to domestic violence (Ghoshal 2020). The decrease could be attributed to confinement at home, constant monitoring (Piquero et al. 2020) and controlling decision-making by the abuser, social isolation of victims from friends and family members (Kaukinen 2020), and reduced options for support (Usher et al. 2020).

Some studies explored the phenomena of domestic violence during and post-disaster in India such as Hines (2007) and Rao (2020). However, existing literature on domestic violence during the lockdown is scarce. Moreover, the lockdown situation is different from other types of disasters. Almost all the states were affected by the presence of this virus at a single time. The question remains as to what factors are associated with an increase in domestic violence during the COVID-19 pandemic? Whether any theoretical framework could explain these factors? Limited studies used routine activity theory (RAT) in unfolding the complex phenomena of domestic violence (Mannon 1997; Roman and Reid 2012). To our knowledge, no study is conducted in India to date that applied the framework of RAT to understand factors resulting in the perpetration of domestic violence, especially during a pandemic. Several authors pitched for the application of criminological theories such as RAT to predict an increase or decrease in crimes during COVID-19 by linking it with specific changes in routine activities (Piquero et al. 2020; Stickle and Felson 2020). Therefore, this paper aims to explore the factors resulting in an increase in domestic violence cases in India during the COVID-19 pandemic by incorporating the routine activity theoretical model. 


\section{A Routine Activity Approach}

Cohen and Felson (1979) propounded RAT while analyzing the change in crime rates in the USA from 1947 to 1974. Instead of emphasizing on idiosyncrasies of offenders like their contemporaries, they focused on factors that facilitate criminal acts (Cohen and Felson 1979). Since then, various studies adopted RAT to explain different types of criminal acts: for example, property crimes (Massey et al. 1989); domestic and intimate partner violence (Mannon 1997); women's stalking victimization; automotive thefts (Rice and Csmith 2002); and cybercrimes (Nguyen 2020).

Cohen and Felson (1979) elucidated three factors that occur together in space and time to give rise to criminal acts: (1) motivated offenders, (2) suitable targets, and (3) absence of capable guardians (Cohen and Felson 1979). A motivated offender is one who is both inclined and able to commit a crime (Felson and Cohen 1980). A suitable target is a person/object which can be threatened by the potential offender (Miro 2014). Lastly, a capable guardian is a person or a thing that can prevent or deter the potential criminal from acting on its evil intentions (Felson and Cohen 1980). According to the theorists, the daily activities of our lives are influenced by the convergence of these three elements in time and space. These daily activities were called routine activities. Felson and Cohen argued that criminal and noncriminal activities are interdependent and that our routine activities, even if legitimate, provide opportunities to commit crime (Felson and Cohen 1980).

In the case of domestic violence, mostly men are seen as perpetrators. Though men also experience domestic violence (Malik and Nadda 2019) but in societies where patriarchy prevails, domestic violence is usually associated with women as victims (Dutt 2018). Felson (1987) identified that offenders often want to put the least amount of effort to carry out the criminal activities such as traveling significantly less distance to find a target and choosing a target who is evident and proximate (Felson 1987). This explains the rise in domestic violence cases during COVID-19, as home became the very space where the three elements that Cohen and Felson identified converged. A motivated offender now has to put in the least amount of effort to find its target.

In its original form, the RAT assumed motivation to be given and placed much attention on the other two factors. Over the years, many researchers tried to interpret RAT from different lens. One of the most popular approaches in understanding violence against women is the feminist interpretation of RAT (Schwartz and Pitts 1995; Mustaine and Tewksbury 2002; Mustaine and Tewksbury 1999; Schwartz et al. 2001; Franklin et al. 2012). The feminist interpretation of RAT stresses the importance of examining societal conditions that facilitates violence against women. This can result in better understanding of the element of motivated offender (Schwartz and Pitts 1995). Borrowing the idea from the feminist interpretation of RAT, we found aspects from the reported and reviewed incidents which can help us understand the factors responsible for fueling persons' motivation to perpetrate violence against their partners during the pandemic. These aspects are discussed in the paper later.

For a crime to occur, the mere presence of a motivated offender is not enough. The presence of a suitable target is equally essential. Felson and Cohen (1980) identified four components that assess the suitability of a target — value, inertia, visibility, and access. In RAT, all these four components are considered from the viewpoint of an offender rather than a target. To understand the factors that made women suitable targets of domestic violence during COVID19, we looked at the four components identified by Cohen and Felson.

A potential offender would be interested in a target if it perceives any value in the target. Value is depended on how desirable the target is to a potential offender. Inertia, on the other 
hand, is the aspect(s) of a person/property that hinders or interferes with its suitability as a target (Felson and Cohen 1980). A suitable target visibility that poses the risk of being discovered by the offender combined with easy accessibility to the target are the other two factors that make a target more suitable (Felson and Cohen 1980). The lockdown order to contain the spread of COVID-19 was passed abruptly in India. This did not give time for women experiencing domestic violence to seek a refuge in safer places. The incidents related to the four attributes of a suitable target are discussed further in detail under the findings.

The final element that the RAT necessitates for a crime to occur is the absence of a capable guardian. The suitability of a target is also dependent on the presence or absence of a capable guardian. Felson (1994) suggested that most crimes can be prevented through informal means of social control. The informal means of social control is usually applied by neighbors, family members, or friends. The control can be applied through threats, watching, and sanctioning (Mannon 1997). Formal means of social control such as police and courts are resorted to when informal means of control fail or prove to be incapable in preventing a crime (Felson 1994). Under the findings we have discussed how limited availability of formal (police and NGOs) and informal sources (family and neighbors) could be a causal factor for the increase in domestic violence.

The application of RAT to understand domestic violence is not limited to the lockdown period. Previous studies documented that one of the unique aspects about applying RAT to understand domestic violence is that the theory focuses on the situational factors related to crime victimization (Mannon 1997; Miethe et al. 1987; Hayes 2018). For example, Hayes (2018) found that the presence of a victim's friends/family contributed to a $60 \%$ decrease in revictimization (Hayes 2018). The study mentioned that examining one of the factors identified by RAT, i.e., the absence of a capable guardian, contributed to a better understanding of domestic violence. Likewise, studying all the three factors identified by the theory could contribute to an in-depth understanding of the situational factors that facilitate domestic violence. This understanding can be helpful in formulating better prevention strategies.

\section{Methodology}

\section{Data Collection}

Firstly, we searched news articles on the Google search engine using a combination of certain keywords. These keywords were "domestic violence," "intimate partner violence," "spousal violence," "marital violence," "lockdown," "COVID-19," "coronavirus," and "India." We used online newspaper sources namely The Economic Times, The Times of India, Scroll.in, The Hindu, The Diplomat, Deccan Herald, The Wire, News18, BBC News, Times Now, and Al Jazeera. Using Google search date and site syntax, we collected news articles published between 22nd March 2020 and 31st May 2020. We collected news articles published in the English language only. Hence, translation and back translation was not required.

\section{Data Analysis}

After data collection from the online newspapers, we arranged the articles chronologically. In total, we analyzed 59 news articles. We analyzed the content of these articles manually. We excluded repetitive articles or articles with no mention of domestic violence incidents or 
associated factors from the analysis. Themes were established a priori rather than adopting an inductive approach (Braun and Clarke 2006). More specifically, we examined incidents of domestic violence reported in these articles to understand how the existing factors resulting in domestic violence perpetration fit into the three factors under RAT. Our pre-existing themes were the three factors under RAT. Initially, both the authors coded the data individually. Later, we exchanged the data to achieve consensus concerning the codes related to appropriate themes. We merged similar codes into a single code. To obtain maximum information, we coded incidents in which more than one code emerged individually. In total, we obtained 27 codes under the three different themes. Any disagreement between the authors was mutually resolved.

\section{Ethical Considerations}

Research participants' safety is of paramount importance while researching domestic violence during COVID-19 (Sexual Violence Research Initiative 2020). Due to the government's guidelines on travel restrictions, we could not go onto the field and collect firsthand data from either victims of domestic violence or institutions working towards domestic violence such as law enforcement agencies, NGOs, Accredit Social Health Activists (ASHA) workers. We also decided not to go for telephonic interviews with domestic violence victims due to their safety and to prevent them from re-victimization. As a feasible option, we decided to collect and review domestic violence cases reported in newspapers during the lockdown period in India. The data used in this article is secondary. Therefore, ethical approval from the Institutional Review Board was not required.

\section{Findings}

\section{Descriptive Statistics}

In total, we reviewed 59 articles that published news related to domestic violence during COVID-19 in India. The majority of the articles were published in The Times of India (13), followed by The Hindu (12), and Hindustan Times (7). There were five articles each in Scroll.in, The Economic Times, and The New India Express; three in The Indian Express; two each in The Diplomat and Al Jazeera; and one each in BBC News, Deccan Herald, News18, Times Now, and The Wire (Table 1). We found 25 incidents of domestic violence wherein the experiences of the victims were described. One incident was repetitive and excluded from the analysis. Additionally, one case was of domestic violence from the parents of the victim and not included in the analysis. The final number of incidents reviewed was 23 .

\section{A Motivated Offender}

From the content analysis, we found a total of nine incidents relevant in understanding the possible motivations of the offender. We found four incidents in which the primary reason for domestic violence was alcohol. In three of the four incidents, the primary reason for perpetrating domestic violence was the abuser experiencing withdrawal symptoms due to the nonavailability of alcohol. In an incident from Hyderabad, a "woman and her teenage son from an earlier marriage, were facing the brunt of her second husband's frustration over not getting 
Table 1 Descriptive statistics of newspaper articles and codes

\begin{tabular}{llll}
\hline $\begin{array}{l}\text { Source (number of articles } \\
\text { collected) }\end{array}$ & Themes & \\
\cline { 2 - 4 } & $\begin{array}{l}\text { A motivated offender } \\
(n)\end{array}$ & $\begin{array}{l}\text { A suitable target } \\
(n)\end{array}$ & $\begin{array}{l}\text { Absence of a capable guardian } \\
(n)\end{array}$ \\
\hline The Times of India (13) & 1 & 2 & - \\
The Hindu (12) & 3 & 3 & 1 \\
Hindustan Times (7) & - & 4 & 2 \\
Scroll.in (5) & - & 1 & - \\
The Economic Times (5) & - & - & - \\
The New India Express (5) & 1 & 2 & 1 \\
The Indian Express (3) & - & 1 & - \\
The Diplomat (2) & 1 & - & - \\
Al Jazeera (2) & - & 1 & 1 \\
Deccan Herald (1) & 2 & - & - \\
News18 (1) & - & 1 & - \\
The Wire (1) & - & 1 & 1 \\
BBC News (1) & - & 1 & 1 \\
Times Now (1) & - & - & \\
\hline
\end{tabular}

$n$, number of codes

alcohol during the lockdown (Joy 2020)." Similarly, one victim of domestic violence told Tamil Nadu police that her husband harassed her daily due to alcohol's non-availability (Kannan 2020). In the third incident, a college-going youth reported that "his father was becoming violent, beating up his mother and even grandmother, because he was having alcohol withdrawals" (Basu 2020). Not only experiencing alcohol withdrawal symptoms but also consuming alcohol was found to be a cause of domestic violence. A domestic violence victim shared that "she was depressed as her husband had taken to alcohol abuse out of anxiety over a financial crisis" (Basu 2020).

The content analysis also indicated unemployment as a factor that fueled the motivation of an offender. We found three incidents in which unemployment and job security were the causes of perpetrating domestic violence. A domestic violence victim shared that her husband lost his factory job recently and beats her in front of her kids (Lal 2020). In the second incident, "a woman from Kolkata was caught at home with her husband who was jobless since the lockdown. He was beating the wife, took away all her savings and was assaulting her in front of her son" (PTI 2020). The third incident was of a woman who worked in a play school... "her husband was told that he may be laid off and she became a target for his ire and insecurity" (Basu 2020).

A related factor that was found to be contributing to the motivation was frustration and anxiety. A victim of domestic violence reported that when her alcoholic husband had a job, things were balanced. After he became unemployed, he stayed at home the entire day, got frustrated, consumed alcohol, and created ruckus (Gatty and Rathee 2020). This reflects the intersection of alcohol consumption, unemployment, and frustration as a cause of domestic violence.

\section{A Suitable Target}

We found and reviewed sixteen cases to understand why the women were suitable targets of domestic violence in the eyes of a motivated offender during the lockdown. From the content analysis, we found the following instances related to the attributes of value and inertia. In one 
incident, a man murdered his wife, in front of his daughter, suspecting her of infidelity (Shivakumar 2020). Basu (2020) reported a similar incident where a woman was allegedly killed by her husband for protesting against his extra-marital affair. In another incident, a Bangalore based woman alleged that her husband stopped opening his grocery store and stopped taking shower after she denied his sexual requests. When the woman refused to have sex with him, he allegedly hit her (News18 2020). The fourth incident was of a 34 years old woman whose husband had abandoned her for eight years for another woman, suddenly returned during lockdown as she continued to stay with his parents. He is now sexually abusing her daily (Basu 2020).

The content analysis also suggested that increased visibility and accessibility of the victim during the lockdown contributed to them being subjected to violence. In one case, a victim of regular verbal and emotional domestic violence claimed that she had her job as a savior from her husband's brutality. Her husband's job also kept him away from her. With the imposition of the lockdown, she had to live in a constant state of fear of victimization (Deshpande 2020). In another case, a victim of domestic violence shared that she would run into the narrow lanes of a slum when she was beaten by her husband. Due to the lockdown and police barricade she could not step out of her house and had to stay indoors (S, R. 2020). A woman from Nainital reported that she is unable to travel to her home in Delhi and her husband is abusing and beating her (Roy 2020a). A similar story was narrated by a 43 years old victim of domestic violence. She was all set to walk out of her marriage and shift into a working women's hostel on April 1. But the COVID-19 lockdown means she is now locked in with her husband and mother-in-law in a two-bedroom flat in Kolkata (Basu 2020).

\section{Absence of a Capable Guardian}

Through the content analysis, we found four relevant incidents related to the absence of a capable guardian. These incidents reflected how the absence of a capable guardian facilitated domestic violence during the lockdown. The prime formal source that acts as a capable guardian against any form of violent crime is the police. Content analysis revealed that there was a shortage of police force during the lockdown. When the pandemic hit the nation, much of the police force was at the frontline, engaged in the strict implementation of lockdown. Many officers were deployed at the containment zones. Others were present at state borders to prevent the entry of people and vehicles from other states. As the police were busy enforcing the lockdown restrictions it was found that cases of police apathy against domestic violence victims also increased (Chandra 2020). In addition, courts were not functioning regularly and were only hearing emergency pleas (Ratnam 2020).

The next formal source that acts as a capable guardian for the victims of domestic violence is the support services. These support services are NGOs, ASHA workers, and counseling services providers. Several NGOs and counseling service providers launched specific helpline numbers to offer support to these victims. But many such helpline reported having received few complaints. For example, a Delhi-based victim of domestic violence sought the help of her brother who was living in Nepal. Her brother reached out to an NGO for help. The NGO with the help of police intervened to mediate between abuser and victim and asked the woman to stay at home during the lockdown. After this intervention, the condition of the woman worsened and she suffered repeated abuse (Ratnam 2020).

Due to lockdown and travel restrictions, victims' parents or family members were not able to intervene physically. In one case from Rajasthan, the complaint was registered by the 
victim's father (Vijayalakshmi and Dev 2020). In another case, the complaint was filed by the victim's brother who was based in Nepal and could not intervene physically (Ratnam 2020). In some cases condition of women who sought help from their parents was deplorable due to mental and financial stress posed by the lockdown. For instance, a victim of verbal and physical abuse by her husband went to her mother's house to save herself just before the first lockdown was imposed. Rather than feeling safe, she started feeling like a burden on her family due to the dipping income and loss of job of her brother. As a result, she was beaten up by her brother (Joy 2020). In general, the travel restrictions imposed by the government limited the ability of victims' families to intervene and act as a capable guardian.

With the travel restrictions and the inability of victim's family to intervene, people who could act as guardians are the neighbors. When victims are locked in with their abusers, neighbors could be the one to act first, intervene and prevent domestic abuse owing to the physical proximity to the victim. In one case, a 9-year-old daughter of a victim of domestic violence sought her neighbor's help, who then intervened and prevented further abuse (Deshpande 2020). However, this was not the case with everyone. Domestic violence in India is seen as a private affair and many people think twice before intervening. In a recent incident, a woman was brutally thrashed by her husband in Uttar Pradesh, which allegedly led to her death. Instead of intervening and helping the woman, the neighbors were seen to be recording the video of the incident (Mirror Now Digital 2020).

\section{Discussion}

The primary objective of this article was to explore the factors resulting in domestic violence during the COVID-19 pandemic in India. From the content analysis of the online newspaper articles, we found that alcohol consumption, unemployment and job uncertainties, and frustrations explained the motivation in offenders. As mentioned earlier, the RAT assumes the motivation of the offender to be given; we borrowed the ideas from the feminist interpretation of RAT that looked at societal conditions facilitating violence against women (Schwartz and Pitts 1995). Therefore, while applying RAT to understand surge in the cases of domestic violence during the pandemic, the above mentioned three factors can be seen as playing a major role in fueling the motivation of a potential offender.

The relationship between alcohol and domestic violence is not something that emerged during COVID-19. Many studies concluded that alcohol does not cause domestic violence. Rather it is seen as a contributing factor towards the perpetration of domestic violence (Graham et al. 2011; Leonard 2001; Moreira et al. 2011). Some studies found that alcohol consumption can increase the risk of perpetrating and severity of violence (Gadd et al. 2019; Graham et al. 2011). A report by the World Health Organisation (WHO) stated that alcohol consumption could severely impact a person's physical and cognitive functioning which reduces the self-control and in turn makes the person incapable of resorting to non-violent means to resolve a conflict in a relationship (World Health Organisation 2006).

Even before the COVID-19 pandemic took over the world, in countries such as India, Uganda, Vietnam, the USA, and Egypt, the correlation between alcohol consumption and domestic violence was very high (World Health Organisation 2006). When countries across the world started imposing lockdowns to control the spread of novel coronavirus, many imposed restrictions on the purchase and sale of alcohol (Narasimha et al. 2020). Countries such as South Africa, Thailand, Greenland, and Sri Lanka imposed either a blanket ban or 
restricted it to particular places where domestic abuse prevalence was high. Alcohol shops were closed for business in India as well when the lockdown was imposed (Neufeld et al. 2020). However, data on domestic violence during the lockdown indicates that the liquor sale ban was not that fruitful.

NCW and many states reported an increase in domestic violence case (Vora et al. 2020). Two reasons can be attributed to understanding this phenomenon. First is the withdrawal from alcohol. Previous research indicates that alcohol withdrawal syndrome contributes to domestic violence (Gadd et al. 2019). During COVID-19 many individuals experienced alcohol withdrawal symptoms due to the non-availability of alcohol (Verma et al. 2020). There was a 4-fold increase in the number of patients with alcohol withdrawal symptoms visiting hospitals (Ahmed et al. 2020). Alcohol withdrawal results in the development of some mental and physical reactions (Varma 2020) and violence could be one of them. It can be argued that alcohol consumption or alcohol withdrawal could be a contributing factor to domestic violence.

Secondly, the ban on alcohol does not mean that consumption also came to a halt. Many black-marketing (Nadkarni et al. 2020) and illegal purchase and sale of alcohol cases were reported (Singh et al. 2020). There were reports of seizure of illicit liquor by the authorities. For example, in the national capital of India, police seized 855 Indian made foreign liquor (IMFL) bottles, 12,509 country made liquor (CML) bottles, and 4868 beer bottles (Ghosh et al. 2020). It can be inferred that alcohol consumption might have come down a little, but it continued as people resorted to illegitimate means to purchase it.

Next source of motivation found was unemployment. Previous studies conducted in India highlighted the association between husband's unemployment and domestic violence (Subodh et al. 2014). Krishnan et al. (2010) found women whose husbands maintained stable employment were less likely to experience domestic violence. Countries across the world faced the employment crisis as COVID-19 affected the functioning of all kinds of businesses. COVID-19 severely hit several sectors of the Indian economy including farming (Mukhopadhyay 2020), tourism, automobile, oil industry, financial market (Mehta and Jha 2020), and sugar industry (Solomon et al. 2020). Until May 2020, India's unemployment rate was at 24\% (Mishra and Rampal 2020). An online survey conducted by Economictimes.com to understand the impact of COVID-19 found that out of the 3,074 respondents, 39\% suffered salary cut and 15\% were about to lose their jobs (Mehta 2020). The National Restaurants Association of India also predicted that without any help from the government and no tax and rent relaxations, 4 out of 10 restaurants in India would not open for business after lockdown is lifted (D’Souza 2020). This spike in unemployment rates, coupled with uncertainty about the future, could contribute to domestic violence. There are predictions that after the world gets through this pandemic, unemployment rates will soar, which would create a surge in domestic violence cases (Godbole 2020; Roy 2020b).

The second element that Cohen and Felson mentioned is a suitable target. As identified earlier the components of value, inertia, visibility and accessibility make a target suitable for the offender. Women's visibility and accessibility during the lockdown made them suitable targets of domestic violence. With the social distancing orders in place and virus spreading rapidly, lot of battered women shelters could not accommodate victims of domestic violence. Due to the lockdown order, many women were in constant proximity to their potential abuser. While quarantine and social distancing are necessary to contain the spread of the virus, it can also lead to social and functional isolation (Gelder et al. 2020). Prior research suggests that the perpetrator's controlling behavior would increase and the lockdown would give them the opportunity to monitor all of their victim's daily activities (Kaukinen 2020; Boserup et al. 2020; Gelder et al. 2020). The proximity would prevent the target from reaching out for help. 
The motivated offender and a suitable target existed in the same space resulting in perpetration of domestic violence.

The third component of the RAT was absence of a capable guardian. A study conducted on married Indian women to understand the help-seeking pattern of victims of domestic violence found that about $60 \%$ of the women reported that they would seek help. These women's first preference was their parents followed by neighbors (Mahapatro et al. 2014). In Indian culture it is a tradition that after marriage woman leaves her parental house and lives with her husband and his family. This limited the physical intervening capacity of the target's family members. On the other hand, in some cases, targets might also fear to approach the neighbors for help thinking that they would be judged negatively by them. As highlighted by Snell-Rood (2015), victims of domestic violence seek emotional help and direct intervention from their neighbors but are reluctant due to stigma. Secondly, neighbors themselves might be reluctant in intervening in the current circumstances as COVID-19 spreads through human contact.

One study found that out of all women who experienced domestic violence, only $4 \%$ approached legal aid cell or NGOs (Kamat et al. 2013). This low approach rate reflects that support service providers cannot intervene unless targets are willing to approach them. Another reason for low approach is lack of resources. The guidelines on essential services by the Ministry of Home Affairs did not make NGOs as essential service (Ministry of Home Affairs 2020). The travel restrictions were applicable to them and limited their physical intervening capability. At best they could forward the complaints received to the law enforcement agencies. The majority of them have telephone helpline numbers, WhatsApp numbers and email addresses to file complaint or request help. However, the telephone numbers were not available $24 * 7$ in some cases. Filing complaint or requesting help through WhatsApp or email provides an advantage that receiver can read it anytime. On the contrary telephonic complaint requires an attendant to receive complaint at the time of the call received. However, the former medium requires a smart phone or computer and an active internet connection. The digital infrastructure of India is not at par with the developed nations. According to Pew Research Centre, only $32 \%$ of the Indian adults use smartphones and $47 \%$ use basic phone that cannot connect to the internet. Moreover, $40 \%$ of men and only $23 \%$ of women use smartphones in India (Silver et al. 2019). In addition to this, only 10.7\% rural and urban households have computer and $23.8 \%$ household have internet facility (National Statistical Office 2019). Both approach of NGOs towards victim and victims' approach towards NGOs limited the role of NGOs as a capable guardian in preventing domestic violence during the pandemic. Further, perpetrators of domestic violence may intensify coercion and control by controlling the technology accessed by the targets. This might include monitoring targets' communication with both formal and informal sources and restricting access to the internet.

RAT states that capable guardian plays a significant role in crime prevention and its absence can result in huge spike in crime rates irrespective of any change in structural conditions motivating the offender. This was observed during the lockdown as well. With no capable guardian to intervene and deter the motivated offender, women became victims of abuse within the four walls of their houses.

\section{Limitations}

There are certain limitations to this article. First is the nature and source of data. This article examined domestic violence cases reported in newspapers that are a secondary source of data. 
The dependence on online newspapers only to search reported cases of domestic violence is a limitation of this study. The limited content in the newspapers limited our ability to distinguish between situational couple violence and domestic violence. While domestic violence is perpetrated to exert a general control over one's partner, there is no general pattern of control in situational couple violence (Johnson and Leone 2005). From the content analysis, we could not identify the context and severity of the violence which is a major limitation of this study. Further, all the newspapers were in the English language. There is a possibility of reporting more cases of domestic violence in local newspapers and in regional languages which this study did not consider. As noted by Carlyle et al. (2008) that newspaper framing of domestic violence is heavily skewed, there is a possibility of selection and reporting bias among journalists about news related to domestic violence.

Second, we used a fairly less number of cases, i.e., 25 to explain the three components of RAT given by Cohen and Felson. Although the cases used in this paper explain the phenomena of domestic violence from the RAT's perspective, we cannot generalize the findings to a larger population. Future studies can collect firsthand data, both qualitative and quantitative, to understand the applicability of RAT to domestic violence.

Third, this study was confined to women as victims of domestic violence. There is sufficient evidence that men also experience domestic violence. For example, Malik and Nadda (2019) reported that one in two married men aged between 21 and 49 years experienced domestic violence from their wives in India. Moreover, individuals from the third gender and different sexual orientations are also victims of violence from their partners (Dank et al. 2013). Future research should extend the application of RAT in domestic violence to other genders and sexual orientation.

Last, there was a discrepancy in reports regarding the magnitude of domestic violence during the COVID-19. While the majority of the sources in India reported an increase in domestic violence complaints than normal during the pandemic, a few sources reported a decrease in complaints related to domestic violence. For example, organizations such as Jagori and Shakti Shalini reported a drop in domestic violence complaints (Ghoshal 2020). Similarly, officials of Karnataka's women and child development department reported a 57\% decrease in domestic violence calls between 23rd March 2020 and 13th April 2020 (Mulla 2020). More empirical studies are required to get a lucid picture.

\section{Conclusion}

Cohen and Felson repeatedly highlighted that changes in our routine activities provide an opportunity to commit more crimes (Cohen and Felson 1979). With the pandemic affecting almost all the countries in the world, there has been a significant change in our routine activities. With India and other countries imposing lockdown or issuing stay-at-home orders, the usual routine activities of people have completely changed. During the lockdown, people did not go out of their homes for work, school, or leisure activities. They were only allowed to step out of their homes to access essential services. People engaged in providing essential services were the only ones who continued with their routine activities even during the lockdown. As Cohen and Felson (1979) highlighted it is the legal routine activities of individuals that provide opportunities for illegal activities (Cohen and Felson 1979). Applying this principle to the issue in hand, the legitimate activity of following a legal order to stay inside the home to contain the spread of COVID-19 resulted in allowing a likely offender who saw their partners as suitable targets to inflict violence, in the absence of capable guardians. 
RAT is applied in a few studies to understand domestic violence. The discussions so far however point out that the importance of RAT in understanding the highly prevalent phenomena of domestic violence cannot be denied. Removal of one of the three factors that facilitate domestic violence from existing in the same time and space, i.e., a motivated offender, suitable target, and absence of a capable guardian could result in a drastic decrease of victims of domestic violence.

\section{Declarations}

Ethical Approval Data used for this study was secondary in nature. No ethical approval from the Institutional Review Board was required.

Informed Consent This study did not involve subjects. Therefore, informed consent was not required.

Conflict of Interest The authors report no conflict of interest.

\section{References}

Abramsky, T., Watts, C. H., Garcia-Moreno, C., Devries, K., Kiss, L., Ellsberg, M., et al. (2011). What factors are associated with recent intimate partner violence? Findings from the WHO multi-country study on women's health and domestic violence. BMC Public Health, 11(1), 109.

Agüero, J. M. (2020). COVID-19 and the rise of intimate partner violence. World Development, 137, 105217.

Ahmed, S., Khaium, M. O., \& Tazmeem, F. (2020). COVID-19 lockdown in India triggers a rapid rise in suicides due to the alcohol withdrawal symptoms: Evidence from media reports. International Journal of Social Psychiatry, 66(8), 827-829.

Basu, S. (2020). A parallel pandemic as domestic abuse victims trapped with their abusers. Retrieved June 25 , 2020, from The Hindu: https:/www.thehindu.com/society/covid-19-lockdown-domestic-abuse-victimstrapped-with-abusers/article31388228.ece.

Begum, S., Donta, B., Nair, S., \& Prakasam, C. P. (2015). Socio-demographic factors associated with domestic violence in urban slums, Mumbai, Maharashtra, India. The Indian Journal of Medical Research, 141(6), 783-788.

Boserup, B., McKenney, M., \& Elkbuli, A. (2020). Alarming trends in US domestic violence during the COVID19 pandemic. The American Journal of Emergency Medicine, 38(12), 2753-2755.

Braun, V., \& Clarke, V. (2006). Using thematic analysis in psychology. Qualitative Research in Psychology, 3(2), 77-101.

Carlyle, K. E., Slater, M. D., \& Chakroff, J. L. (2008). Newspaper coverage of intimate partner violence: skewing representations of risk. Journal of Communication, 58(1), 168-186.

Chandra, J. (2020). Covid-19 lockdown | Rise in domestic violence, police apathy: NCW. Retrieved July 20, 2020, from https:/www.thehindu.com/news/national/covid-19-lockdown-spike-in-domestic-violence-saysncw/article31238659.ece.

Cohen, L. E., \& Felson, M. (1979). Social change and crime rate trends: a routine activity approach. American Sociologial Review, 44(4), 588-608.

D'Souza, O. (2020). Layoffs, salary cuts become new COVID-19 norm. Retrieved June 21, 2020, from The New India Express: https://www.newindianexpress.com/cities/delhi/2020/may/26/layoffs-salary-cuts-becomenew-covid-19-norms-2148098.html.

Dalal, K., \& Lindqvist, K. (2012). A national study of the prevalence and correlates of domestic violence among women in India. Asia-Pacific Journal of Public Health, 24(2), 265-277.

Dank, M., Lachman, P., Zweig, J. M., \& Yahner, J. (2013). Dating violence experiences of lesbian, gay, bisexual, and transgender youth. Journal of Youth and Adolescence, 43(5), 846-857.

Deshpande, N. (2020). What India's lockdown did to domestic abuse victims. Retrieved June 23, 2020, from BBC News: https://www.bbc.com/news/world-asia-india-52846304.

Dutt, A. (2018). Locating patriarchy in violence against women in India: social, legal and alternative responses. PEOPLE: International Journal of Social Sciences, 4(2), 212-228.

Felson, M. (1987). Routine activities and crime prevention in the developing metropolis. Criminology, 25(4), 911-932. 
Felson, M. (1994). Crime and everyday life: Insights and implications for society. Thousand Oaks, CA: Pine Forge Press.

Felson, M., \& Cohen, L. E. (1980). Human ecology and crime: a routine activity approach. Human Ecology, $8(4), 389-406$.

Fisher, S. (2010). Violence against women and natural disastrs: findings from post-tsunami Sri Lanka. Violence Against Women, 16(8), 902-918.

Fitz-Gibbon, K., Pfitzner, N., True, J., Walklate, S., Meyer, S., Segrave, M., et al. (2020). COVID-19 and the increase of domestic violence against women. Melbourne: Monash University.

Franklin, C. A., Franklin, T. W., Nobles, M. R., \& Kercher, G. A. (2012). Assessing the effect of routine activity theory and self-control on property, personal, and sexual assault victimization. Criminal Justice and Behaviour, 39(10), 1296-1315.

Gadd, D., Henderson, J., Radcliffe, P., Stephens-Lewis, D., Johnson, A., \& Gilchrist, G. (2019). The dynamics of domestic abuse and drug and alcohol dependency. The British Journal of Criminology, 59(5), 1035-1053.

Garg, S., Singh, M. M., Rustagi, R., Engtipi, K., \& Bala, I. (2019). Magnitude of domestic violence and its sociodemographic correlates among pregnant women in Delhi. Journal of Family Medicine and Primary Care, $8(11), 3634-3639$.

Gatty, H. R., \& Rathee, P. (2020). How lockdown + unemployment + hunger + liquor increased domestic conflicts in low income households. Retrieved June 22, 2020, from Citizen Matters: https://bengaluru. citizenmatters.in/covid-19-lockdown-psychological-effects-mental-health-46426.

Gebrewahd, G. T., Gebremeskel, G. G., \& Tadesse, D. B. (2020). Intimate partner violence against reproductive age women during COVID-19 pandemic in northern Ethiopia 2020: a community-based cross-sectional study. Reproductive Health, 17(1), 1-8.

Gelder, N. v., Peterman, A., Potts, A., O’Donnell, M., Thompson, K., Shah, N., et al. (2020). COVID-19: Reducing the risk of infection might increase the risk of intimate partner violence. EClinical Medicine, 21.

Ghosh, A., Choudhury, S., Basu, A., Mahintamani, T., Sharma, K., Pillai, R. R., et al. (2020). Extended lockdown and India's alcohol policy: a qualitative analysis of newspaper articles. International Journal of Drug Policy, 85, 102940.

Ghoshal, R. (2020). Twin public health emergencies: Covid-19 and domestic violence. Indian Journal of Medical Ethics, 5, 195-199.

Godbole, T. (2020). Domestic violence rises amid coronavirus lockdowns in Asia. Retrieved June 5, 2020, from DW News: https://www.dw.com/en/domestic-violence-rises-amid-coronavirus-lockdowns-in-asia/a53077378.

Graham, K., Bernards, S., Wilsnack, S. C., \& Gmel, G. (2011). Alcohol may not cause partner violence but it seems to make it worse: A cross national comparison of the relationship between alcohol and severity of partner violence. Journal of Interpersonal Violence, 26(8), 1503-1523.

Hayes, B. E. (2018). Repeat victimization among intimate partner violence victims: The impact of guardianship. Feminist Criminology, 13(2), 138-159.

Hines, R. I. (2007). Natural disasters and gender inequalities: The 2004 tsunami and the case of India. Race, Gender \& Class, 14(1-2), 60-68.

International Institute for Population Sciences (IIPS) and ICF. (2017). National Family Health Survey (NFHS-4), 2015-16: India. Mumbai: IIPS.

Johnson, M. P., \& Leone, J. M. (2005). The differential effects of intimate terrorism and situational couple violence: findings from the National Violence Against Women Survey. Journal of Family Issues, 26(3), $322-349$.

Joy, S. (2020). Coronavirus crisis: no lockdown for domestic violence. Retrieved June 22, 2020, from Deccan Herald: https://www.deccanherald.com/specials/insight/coronavirus-crisis-no-lockdown-for-domesticviolence-829941.html.

Kalokhe, A., del Rio, C., Dunkle, K., Stephenson, R., Metheny, N., Paranjape, A., et al. (2016). Domestic violence against women in India: a systematic review of a decade of quantitative studies. Global Public Health, 12(4), 498-513.

Kamat, U. S., Ferreira, A. M., Mashelkar, K., Pinto, N. R., \& Pirankar, S. (2013). Domestic violence against women in rural Goa (India): prevalence, determinants and help-seeking behaviour. International Journal of Health Sciences \& Research, 3(9), 65-71.

Kannan, S. (2020). Domestic violence cases in Chennai up, cops get 25 calls a day. Retrieved April 18, 2020, from The Times of India: https://m.timesofindia.com/city/chennai/domestic-violence-cases-in-chennai-upcops-get-25-calls-a-day/articleshow/75153610.cms.

Kaukinen, C. (2020). When stay-at-home orders leave victims unsafe at home: exploring the risk and consequences of intimate partner violence during the COVID-19 pandemic. American Journal of Criminal Justice, 45, 668-679. 
Krishnan, S., Rocca, C. H., Hubbard, A. E., Subbiah, K., Edmeades, J., \& Padian, N. S. (2010). Do changes in spousal employment status lead to domestic violence? Insights from a prospective study in Bangalore, India. Social Science \& Medicine, 70(1), 136-143.

Lal, N. (2020). India's 'Shadow Pandemic'. Retrieved June 22, 2020, from The Diplomat: https://thediplomat. com/2020/04/indias-shadow-pandemic/.

Leonard, K. (2001). Domestic violence and alcohol: what is known and what do we need to know to encourage environmental interventions? Journal of Substance Use, 6(4), 235-247.

Mahapatro, M., Gupta, R. N., \& Gupta, V. K. (2014). Control and support models of help-seeking behavior in women experiencing domestic violence in India. Violence and Victims, 29(3), 464-475.

Mahase, E. (2020). COVID-19: EU states report $60 \%$ rise in emergency calls about domestic violence. BMJ: British Medical Journal (Online), 369.

Malik, J. S., \& Nadda, A. (2019). A cross-sectional study of gender-based violence against men in the rural area of Haryana, India. Indian Journal of Community Medicine, 44(1), 35-38.

Mannon, J. M. (1997). Domestic and intimate violence: an application of routine activities theory. Aggression and Violent Behavior, 2(1), 9-24.

Massey, J. L., Krohn, M. D., \& Bonati, L. M. (1989). Property crime and the routine activities of individuals. Journal of Research in Crime and Delinquency, 26(4), 378-400.

Mehta, R. (2020). Covid impact: 2 in 5 employees are facing salary cuts, finds survey. Retrieved June 21, 2020, from The Economic Times: https://economictimes.indiatimes.com/wealth/personalfinance-news/covid-impact-2-in-5-employees-are-facing-salary-cuts-finds-survey/articleshow/ 75502876.cms?from $=$ mdr.

Mehta, K., \& Jha, S. S. (2020). COVID-19: a nightmare for the Indian economy. Purakala, 31(20), 333-347.

Miethe, T. D., Stafford, M. C., \& Long, J. S. (1987). Social differentiation in criminal victimization: A test of routine activities/lifestyle theories. American Sociological Review, 52(2), 184-194.

Ministry of Home Affairs (2020). Guidelines of MHA on essential services in view of Covid 19 outbreak crisis and national lockdown. Retrieved June 20, 2020, from Ministry of Food Processing Industries: https://mofpi. nic.in/sites/default/files/mha_order_and_guidline_as_on_24.03.2020.pdf.

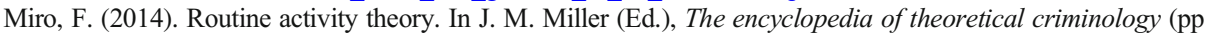
1-7). London: Blackwell Publishing Ltd.

Mirror Now Digital (2020). UP: Man beats wife to death in Raebareli, viral video becomes 'evidence' against him. Retrieved June 7, 2020, from Mirror Now News: https://www.timesnownews.com/mirror-now/crime/ article/up-man-beats-wife-to-death-in-raebareli-viral-video-becomes-evidence-against-him/601258.

Mishra, K., \& Rampal, J. (2020). The COVID-19 pandemic and food insecurity: A viewpoint on India. World Development, 135, 105068.

Moreira, T. d., Ferigolo, M., Fernandes, S., Barros, X., Mazoni, C. G., Noto, A. R., et al. (2011). Alcohol and domestic violence: A cross-over study in residences of individuals in Brazil. Journal of Family Violence, 26(6), 465-471.

Mukhopadhyay, B. R. (2020). COVID-19 and the Indian farm sector: Ensuring everyone's seat at the table. Agriculture and Human Values, 37, 549-550.

Mulla, J. A. (2020). Domestic violence calls to 181 helpline dip during lockdown. Retrieved April 18, 2020, from The Times of India: https://timesofindia.indiatimes.com/city/hubballi/domestic-violence-calls-to-181helpline-dip-during-lockdown/articleshow/75164334.cms?from=mdr.

Mustaine, E. E., \& Tewksbury, R. (1999). A routine activity theory explanation for women's stalking victimizations. Violence Against Women, 5(1), 43-62.

Mustaine, E. E., \& Tewksbury, R. (2002). Sexual assault of college women: A feminist interpretation of a routine activities analysis. Criminal Justice Review, 27(1), 89-123.

Nadkarni, A., Kapoor, A., \& Pathare, S. (2020). COVID-19 and forced alcohol abstinence in India: The dilemmas around ethics and rights. International Journal of Law and Psychiatry, 71, 101579.

Narasimha, V. L., Shukla, L., Mukherjee, D., Menon, J., Huddar, S., Panda, U. K., et al. (2020). Complicated alcohol withdrawal-An unintended consequence of COVID-19 lockdown. Alcohol and Alcoholism, 55(4), $350-353$.

National Statistical Office. (2019). Key indicators of household social consumption on education in India. New Delhi: Government of India.

Neufeld, M., Lachenmeier, D. W., Ferreira-Borges, C., \& Rehn, J. (2020). Alcohol an "essential good" during COVID-19? yes, but only as a disinfectant! Alcoholism: Clinical and Experimental Research, 44(9), 19061909.

News 18 (2020). Bengaluru woman reports husband after he stops showering and demands sex during lockdown. Retrieved June 23, 2020, from News 18: https:/www.news18.com/news/buzz/bengaluru-woman-reportshusband-after-he-stops-showering-and-demands-sex-during-lockdown-2584707.html. 
Nguyen, T. V. (2020). Cybercrime in Vietnam: An analysis based on routine activity theory. International Journal of Cyber Criminology, 14(1), 156-173.

Outlook (2020). Domestic violence tops crime against women in 2018: NCRB. Retrieved April 19, 2020, from Outlook: https://www.outlookindia.com/newsscroll/domestic-violence-tops-crime-against-women-in-2018ncrb/1704114.

Pallikadavath, S., \& Bradley, T. (2019). Dowry, 'dowry autonomy' and domestic violence among young married women in India. Journal of Biosocial Science, 51(3), 353-373.

Parkinson, D. (2019). Investigating the increase in domestic violence post disaster: An Australian case study. Journal of Interpersonal Violence, 34(11), 2333-2362.

Pengpid, S., \& Peltzer, K. (2018). Lifetime spousal violence victimization and perpetration, physical illness, and health risk behaviours among women in India. International Journal of Environmental Research and Public Health, 15(12), 2737.

Peter, P. (2020). Domestic violence calls up from 10 to 25 a day during lockdown in Bengaluru. Retrieved April 18, 2020, from The Times of India: https:/timesofindia.indiatimes.com/city/bengaluru/domestic-violencecalls-up-from-10-to-25-a-day-during-lockdown/articleshow/75073669.cms?from=mdr.

Piquero, A. R., Riddell, J. R., Bishopp, S. A., Narvey, C., Reid, J. A., \& Piquero, N. L. (2020). Staying home, staying safe? A short-term analysis of COVID-19 on Dallas domestic violence. American Journal of Criminal Justice, 45, 601-635.

PTI (2020). COVID-19 lockdown: You can now report domestic violence using this signal. Retrieved June 13, 2020, from The New Indian Express: https://www.newindianexpress.com/nation/2020/apr/04/covid-19lockdown-you-can-now-report-domestic-violence-using-this-signal-2125720.html.

Ram, A., Victor, C. P., Christy, H., Hembrom, S., Cherian, A. G., \& Mohan, V. R. (2019). Domestic violence and its determinants among 15-49-year-old women in a rural block in South India. Indian Journal of Community Medicine, 44(4), 362-367.

Rao, S. (2020). A natural disaster and intimate partner violence: Evidence over time. Social Science \& Medicine, $247,112804$.

Ratnam, D. (2020). Domestic violence during Covid-19 lockdown emerges as serious concern. Retrieved June 14, 2020, from Hindustan Times: https:/www.hindustantimes.com/india-news/domestic-violenceduring-covid-19-lockdown-emerges-as-serious-concern/story-mMRq3NnnFvOehgLOOPpe8J.html.

Rice, K. J., \& Csmith, W. R. (2002). Socioecological models of automotive theft: Integrating routine activity and social disorganization approaches. Journal of Research in Crime and Delinquency, 39(3), 304-336.

Roman, C. G., \& Reid, S. E. (2012). Assessing the relationship between alcohol outlets and domestic violence: Routine activities and the neighborhood environment. Violence and Victims, 27(5), 811-828.

Roy, E. (2020a). Domestic violence, abuse complaints rise in coronavirus lockdown: NCW. Retrieved June 15, 2020, from The Indian Expess: https://indianexpress.com/article/india/domestic-violence-abuse-complaintsrise-in-coronavirus-lockdown-ncw-6344641/.

Roy, I. (2020b). From abuse to jobs, the crisis will burden women more than men. Retrieved June 5, 2020, from The Wire: https://thewire.in/women/covid-19-domestive-abuse.

S, R. (2020). Locked down with abusers: India sees surge in domestic violence. Retrieved May 6, 2020, from Al Jazeera: https://www.aljazeera.com/news/2020/04/locked-abusers-india-domestic-violence-surge200415092014621.html.

Schwartz, M. D., \& Pitts, V. L. (1995). Exploring a feminist routine activities approach to explaining sexual assault. Justice Quarterly, 12(1), 9-31.

Schwartz, M. D., DeKeseredy, W. S., Tait, D., \& Alvi, S. (2001). Male peer support and a feminist routine activities theory: Understanding sexual assault on the college campus. Justice Quarterly, 18(3), 623-649.

Sediri, S., Zgueb, Y., Ouanes, S., Ouali, U., Bourgou, S., Jomli, R., et al. (2020). Women's mental health: Acute impact of COVID-19 pandemic on domestic violence. Archives of Women's Mental Health, 23, 749-756.

Sexual Violence Research Initiative (2020). Considerations for doing intimate partner violence research in the time of roronavirus. Retrieved June 10, 2020, from Sexual Violence Research Initiative: https://www.svri. org/blog/considerations-doing-intimate-partner-violence-research-time-coronavirus.

Sharma, G. D., Talan, G., \& Jain, M. (2020). Policy response to the economic challenge from COVID-19 in India: A qualitative enquiry. Journal of Public Affairs, 20(4), e2206.

Shivakumar, G. (2020). While battling COVID-19, we can't let the pandemic of domestic violence continue. Retrieved June 23, 2020, from The Wire: https://thewire.in/women/covid-19-lockdown-domestic-violence.

Silver, L., Smith, A., Johnson, C., Taylor, K., Jiang, J., Anderson, M., et al. (2019). Mobile connectivity in emerging economies. Washington: Pew Research Center.

Singh, S., Sharma, P., \& Balhara, Y. P. (2020). The impact of nationwide alcohol ban during the COVID-19 lockdown on alcohol use-related internet searches and behaviour in India: An infodemiology study. Drug and Alcohol Review, 40(2), 196-200. 
Sinha, A., Mallik, S., Sanyal, D., Dasgupta, S., Pal, D., \& Mukherjee, A. (2012). Domestic violence among ever married women of reproductive age group in a slum area of Kolkata. Indian Journal of Public Health, 56(1), 31-36.

Snell-Rood, C. (2015). Informal support for women and intimate partner violence: The crucial yet ambivalent role of neighbours in urban India. Culture, Health and Sexuality, 17(1), 63-77.

Solomon, S., Rao, G. P., \& Swapna, M. (2020). Impact of COVID-19 on Indian sugar industry. Sugar Tech, 22, 547-551.

Stephenson, R., Jadhav, A., Winter, A., \& Hindin, M. (2016). Domestic violence and abortion among rural women in four Indian states. Violence Against Women, 22(13), 1642-1658.

Stickle, B., \& Felson, M. (2020). Crime rates in a pandemic: The largest criminological experiment in history. American Journal of Criminal Justice, 45(4), 525-536.

Subodh, N. B., Grover, S., Grewal, M., Grewal, S., Basu, D., \& Mattoo, S. K. (2014). Interpersonal violence against wives by substance dependent men. Drug and Alcohol Dependence, 138, 124-129.

UN Women (2020). Violence against women and girls: The shadow pandemic. Retrieved November 8, 2020, from UN Women: https:/www.unwomen.org/en/news/stories/2020/4/statement-ed-phumzile-violenceagainst-women-during-pandemic.

Usher, K., Bhullar, N., Durkin, J., Gyamfi, N., \& Jackson, D. (2020). Family violence and COVID-19: Increased vulnerability and reduced options for support. International Journal of Mental Health Nursing, 29, 549-552.

Varma, R. P. (2020). Alcohol withdrawal management during the Covid-19 lockdown in Kerala. Indian Journal of Medcial Ethics, 2, 105.

Verma, S., Saharan, A., Polcumpally, A. T., \& Biswas, M. (2020). Tentacles of COVID-19 in India: Impact on Indian economy, society, polity and geopolitics. Journal of Humanities and Social Sciences Studies, 2(3), 54-61.

Vijayalakshmi, A., \& Dev, P. (2020). No lockdown for abuse. Retrieved June 12, 2020, from The Hindu: https:// www.thehindu.com/opinion/op-ed/no-lockdown-for-abuse/article31292334.ece.

Vora, M., Malathesh, B. C., Das, S., \& Chatterjee, S. S. (2020). COVID-19 and domestic violence against women. Asian Journal of Psychiatry, 53, 102227.

Weitzman, A. (2019). The sex of firstborn children and intimate partner violence in India. Violence Against Women, 26(6-7), 590-613.

World Health Organisation. (2006). Intimate partner violence and alcohol. Geneva: World Health Organisation.

Xue, J., Chen, J., Chen, C., Hu, R., \& Zhu, T. (2020). The hidden pandemic of family violence during COVID19: Unsupervised learning of tweets. Journal of Medical Internet Research, 22(11), e24361.

Publisher's Note Springer Nature remains neutral with regard to jurisdictional claims in published maps and institutional affiliations. 